\title{
The Relation Between the Severity of Androgenetic Alopecia and Cardiovascular Atherosclerosis Measured Via Carotid Intima- Media Thickness and the Syntax Score
}

\author{
Androgenetik Alopesi Ciddiyeti ile Karotid Intima-Media Kalınlığı ve SYNTAX skoru ile ölçülen Kardiyovasküler \\ Ateroskleroz Ilișkisi
}

Hüseyin Ede ${ }^{1}$, Emine Çölgeçen², Mustafa Fatih Erkoç3 ${ }^{3}$ Yurdanur Akyüz³ , Ali Rıza Elbay ${ }^{1}$

Bozok University School of Medicine, Department of Cardiology,
Yozgat, Turkey
Bozok University School of Medicine, Department of Dermatology,
Yozgat, Turkey
Bozok University School of Medicine, Department of Radiology,
Yozgat, Turkey
Received : June 22, 2015 • Accepted: March 18, 2016

\section{Corresponding author:}

Assist. Prof. Dr Hüseyin Ede

E-mail: huseyinede@gmail.com

Tel: +905056711104

Faks: +90 3542123739

Bozok Üniv. Tıp Fakültesi Kardiyoloji Anabilim Dalı 6200 Yozgat/TURKEY

Amaç: Androgenetik alopesi (AGA) ile karotid intima-media kalınlığı (KiMK) ve SYNTAX skoru ile ölçülen kardiyovasküler ateroskleroz arasındaki ilișkiyi araștırmayı amaçladık.

Gereç ve Yöntem: Koroner anjiyografi endikasyonu konulmus yüz onaltı hasta prospektif olarak çalıșmaya dahil edildi. Hamilton kellik skalası (erkekler için) ve Ludwig kellik skalası (kadınlar için) kullanılarak AGA sınıflandıııldı. Hastalar, kellik skala derecelerine göre üç gruba ayrıldı. Her bir hastanın SYNTAX skoru ve KiMK değeri uygun biçimde ölçüldü. Kaın ve erkek hastaların verileri ayrı ayrı değerlendirildi.

Bulgular: Erkeklerde; 3. grup ( $n=15), 1$ gruba $(n=14)$ ve 2. gruba $(n=35)$ göre belirgin biçimde daha yüksek SYNTAX skoruna sahipti. Benzer sekilde, kadınlarda da 3. grup $(n=12)$, 1 gruba $(n=29)$ ve 2 . gruba $(n=14)$ göre belirgin biçimde daha yüksek SYNTAX skoruna sahipti. Hem kadınlarda hem de erkeklerde 3. grup diğerlerine göre daha yüksek KiMK değerine sahipti.

Sonuç: Androgenetik alopesi, kardiyovasküler aterosklerozun basit bir göstergesi olabilir çünkü her iki cinsiyette de yüksek AGA seviyelerine sahip olan hastalar belirgin olarak daha yüksek SYNTAX skoruna ve KIMK değerine sahip olduğunu bulduk.

Anahtar Sözcükler: Androgenetik Alopesi; Ateroskleroz; Karotid intima-Media Kalınlığı, SYNTAX Skoru Objectives: We aimed to search the relation between androgenetic alopecia (AGA) and cardiovascular atherosclerosis measured via carotid intima-media thickness (CIMT) and the SYNTAX score.

Material-Methods: One hundred and sixteen subjects with an indication for coronary angiography were prospectively enrolled into the study. AGA was classified according to the Hamilton baldness scale (for males) and Ludwig scale (for females). Subjects were separated into three groups according to degree of their baldness scale. The SYNTAX score and CIMT were measured for each subject accordingly. Analyses of male and female subjects were carried out separately.

Results: For male subjects; group $3(n=15)$ had significantly higher SYNTAX score compared to group 1 $(n=14)$ and group $2(n=35)$. Similarly for female subjects, group $3(n=12)$ had significantly higher SYNTAX score compared to group $1(n=29)$ and group $2(n=14)$. Among both male and female subjects, CIMT of group 3 were significantly higher than that of other groups.

Conclusion: AGA may be a simple phenotypical indicator for cardiovascular atherosclerosis since we found that patients with higher stage of AGA had significantly higher SYNTAX score and CIMT value among both gender.

Key Words: Androgenetic Alopecia; Atherosclerosis; Carotid Intima-Media Thickness; the SYNTAX Score

Androgenetic alopecia (AGA), the most commonly found baldness pattern among males, is hereditary loss of frontal and vertex scalp hair induced by the effect of androgenic hormones in individual with genetic tendency (1). This develops from third decade onwards in males. The frequency of any degree of AGA can be up to $80 \%$ among men throughout their life (2). Although pathophysiology has not been documented totally; androgens, particularly dihyr- dotestesterone (DHT), play a pivotal role in development of male pattern baldness (3). AGA is inherited with a complex polygenic pattern (3). There is an escalating amount of evidence implying relation between male type baldness and coronary artery disease (CAD) (4). Though, mechanism of this relation has not been defined totally, elevated serum DHT/ testosterone ratio rather than increased serum testosterone level is found to be important in the pathophysiology (5-7). 
Physiological doses of testosterone replacement were proven to reduce cardiovascular adverse events in case of testosterone deficiency while supraphysiological doses were reported to induce adverse cardiovascular events $(5,7)$.

Female AGA is a cosmetically disturbing condition effecting millions of women. Generally, female AGA is not related with elevated androgens as male AGA. Rather, women with female AGA may have other dermatological or general findings of hyperandrogenism such as hirsutism, acne, irregular menses, infertility, galactorrhea and insulin resistance (8).

CAD is a leading cause of mortality and morbidity in adults. Prompt diagnosis and treatment are vital for the better clinical outcome. Thus, signs for early-onset atherosclerosis such as increased carotid intima-media thickness (CIMT), arterial stiffness, and epicardial fat tissue thickness should be considered in the evaluation of coronary atherosclerosis (9). The coronary angiography is a gold standard invasive diagnostic tool for CAD. The simplest way to evaluate state of coronary artery atherosclerosis is measurement of luminal stenosis in percentage. Stenosis of more than $>50 \%$ is considered as severe. But this value solely cannot enough to reflect the whole picture. Thus, the SYNTAX (Synergy between PCI with Taxus and Cardiac Surgery) score was developed to evaluate severity and extent of CAD (10)..

Although AGA both in males and females has relation with cardiovascular risk, still there are some controversial aspects (11). To enlighten these controversies, we aimed at search the relation between AGA and cardiovascular atherosclerosis measured via CIMT and the SYNTAX score.

\section{Materials and Methods}

\section{Study population}

Following the ethical approval and informed consent of each patient, the investigation was performed in accordance with the principles outlined in the Declaration of Helsinki. All subjects were enrolled prospectively from the patients aged between 18 to 65 years referred to cardiology department with an indication for coronary angiography between September 2013 and August 2014. In this duration, 451 subjects were undergone conventional coronary angiography. Of these 451 subjects, one hundred and sixteen consecutive patients (61 males and 55 females) were found to be eligible for the study based on our predefined exclusion criteria as follows: patients with acute coronary syndrome, previously diagnosed coronary, cerebral, and peripheral arterial disease, presence of chronic kidney disease, congestive heart failure, left ventricular ejection fraction (LVEF) of $<50 \%$, thyroid, hypophysis, and adrenal disorders, current or previous usage of medication for alopecia, and use of drugs such as androgen, anti-androgen, weight loss or insulin sensitizing drugs and glucocorticoids within the last 3 months. Age, gender, height, and weight of each subject were recorded. Body mass index of all subjects were calculated. Presence of any cardiovascular risk factors (diabetes mellitus, hypertension, family history of premature CAD before 55 years old, cigarette smoking) was recorded, current use of any medication for relevant risk factor was accepted as positive for presence of cardiovascular risk factor in concern. Laboratory examination for fasting lipid profile, glucose, thyroid stimulating hormone, creatinine, and whole blood count was carried out. Echocardiographic examination of the all subjects was carried out and LVEF and left atrium diameter were measured accordingly.

\section{Assessment of AGA}

AGA in males was classified according to the Hamilton baldness scale, as modified by Norwood (12). Two trained physicians blinded to clinical data of the subjects separately observed the subject's head from two views (side and top), compared the subject's hair pattern to Hamilton baldness scale and chose the best matching stage of the scale on consensus. Then, subjects were classified into three groups to make analysis easier (13). The mild group included AGA stage I, II and IIa; the moderate group consisted of AGA stage III, IIIa, III vertex, IV, $\mathrm{IVa}, \mathrm{V}$ and $\mathrm{Va}$; the severe group included AGA stage VI and VII according to Hamilton-Norwood scale.

The female patients were enrolled into three classes in accordance with Ludwig scale as follows: stage I, stage II, and stage III (14). In similar fashion, two trained physicians blinded to clinical data of the subjects separately observed the subject's head from two views (side and top), compared the subject's hair pattern to Ludwig baldness scale and chose the best matching stage of the scale on consensus.

\section{SYNTAX score calculation}

CAG was performed using a Philips Allura Xper FD10 (Netherlands) coronary angiography device equipped with the cardiovascular angiography analysis system. Following the CAG, the SYNTAX score was calculated retrospectively and offline by two trained operators blinded to clinical data of the subjects on consensus. The SYNTAX score was determined for all coronary lesions with $>50 \%$ diameter stenosis in a vessel $>1.5 \mathrm{~mm}$ in diameter, based on the SYNTAX Score Calculator 2.11 (www.syntaxscore.com).

\section{CIMT measurement}

Carotid doppler ultrasonography was performed with an Aloca prosound A6 (Hitachi Aloca Medical, America) equipped with a $7.5 \mathrm{MHz}$ linear array imaging probe. All measurements were performed under ECG monitoring in the diastole by the same radiologist blinded to clinical data of the subjects while the patient was lying supine, the head was directed away from the side of interest and the neck was extended slightly. To maximize the lumen diameter, transducer located in longitudinal plane. At a location of $1 \mathrm{~cm}$ proximal to the carotid bifurcation the images were magnified to achieve a higher resolution of detail. CIMT of the far wall was evaluated as the distance between the lumen- 
intima interface and the mediaadventitia interface. Measurements were obtained from five contiguous sites at $1-\mathrm{mm}$ intervals bilaterally, and the average of the all measurements of the patient was used for the statistical analyses. CIMT values more than $1 \mathrm{~mm}$ was accepted as abnormal.

\section{Statistical analysis}

All statistical analyses were performed using the SPSS software program. Continuous variables are expressed in mean $\pm \mathrm{SD}$ and categorical variables are presented as frequencies (\%). Except the SYNTAX score of female subjects and age, LVEF, creatinine, and high density lipoprotein of male subjects, the other continuous variables of both gender showed normal distribution according to Kolmogorov-Smirnov test. Categorical variables were compared using the chisquare test. Pearson or Spearman simple correlation analyses were performed to determine the association between continuous parameters accordingly. Kruskal-Wallis tests were used to compare the difference of three groups in respect to nonnormal-distributed variables while ANOVA was used to test significance of the difference for three groups in respect to normally distributed variables. Binary logistic regression analysis was performed to detect the indicator for presence of SYNTAX score $>0$ among cardiovascular risk factors and presence of AGA (stage of III and above was accepted as presence of AGA) into the model. A p value of less than 0.05 was accepted as statistically significant result.

\section{Results}

One hundred and sixteen patients (61 males and 55 females) were included in the study. Group 1, 2, and 3 of the male patients included 12,34 , and 15 subjects respectively while group 1,2 , and 3 of the female patients consisted of 29,14 , and 12 subjects respectively. Average age, height, weight, and BMI of groups of males and females were statistically similar (Table 1). Similarly, echocardiographic measurements of groups in both males and females did not show significant difference (Table 2). Frequencies of the subjects in respect to zero, low-, intermediate-, and high-risk SYNTAX score were expressed in Table 2. It was observed that severity of the CAD increased as the AGA stage increased both in males and females. In the analyses of the SYNTAX scores in male subjects; group 3 had significantly higher SYNTAX score compared to group 1 ( $\mathrm{z}$ score -4.426 and $\mathrm{p}<0.001)$ and group 2 ( $\mathrm{z}$ score 2.812 and $\mathrm{p}<0.01)$.Similarly, CIMT value of group 3 in males were higher than that of group 1 ( $z$ score -4.221 and $\mathrm{p}<0.001)$ and that of group 2 ( $\mathrm{z}$ score -2.433, $\mathrm{p}<0.05)$.

Similar analyses were performed for the groups of female subjects, group 3 had significantly higher score compared to group 1 ( $\mathrm{z}$ score -5.815 and $\mathrm{p}<0.001)$ and group 2 ( $z$ score -3.759 and $\mathrm{p}<0.001)$. Similarly, CIMT value of group 3 in males were higher than that of group 1 ( $z$ score -5.021 and $\mathrm{p}<0.001)$ and that of group 2 ( $\mathrm{z}$ score $-4.083, \mathrm{p}<0.001)$.

Table 1: Clinical, echocardiographic data, and the SYNTAX scores of the subjects.

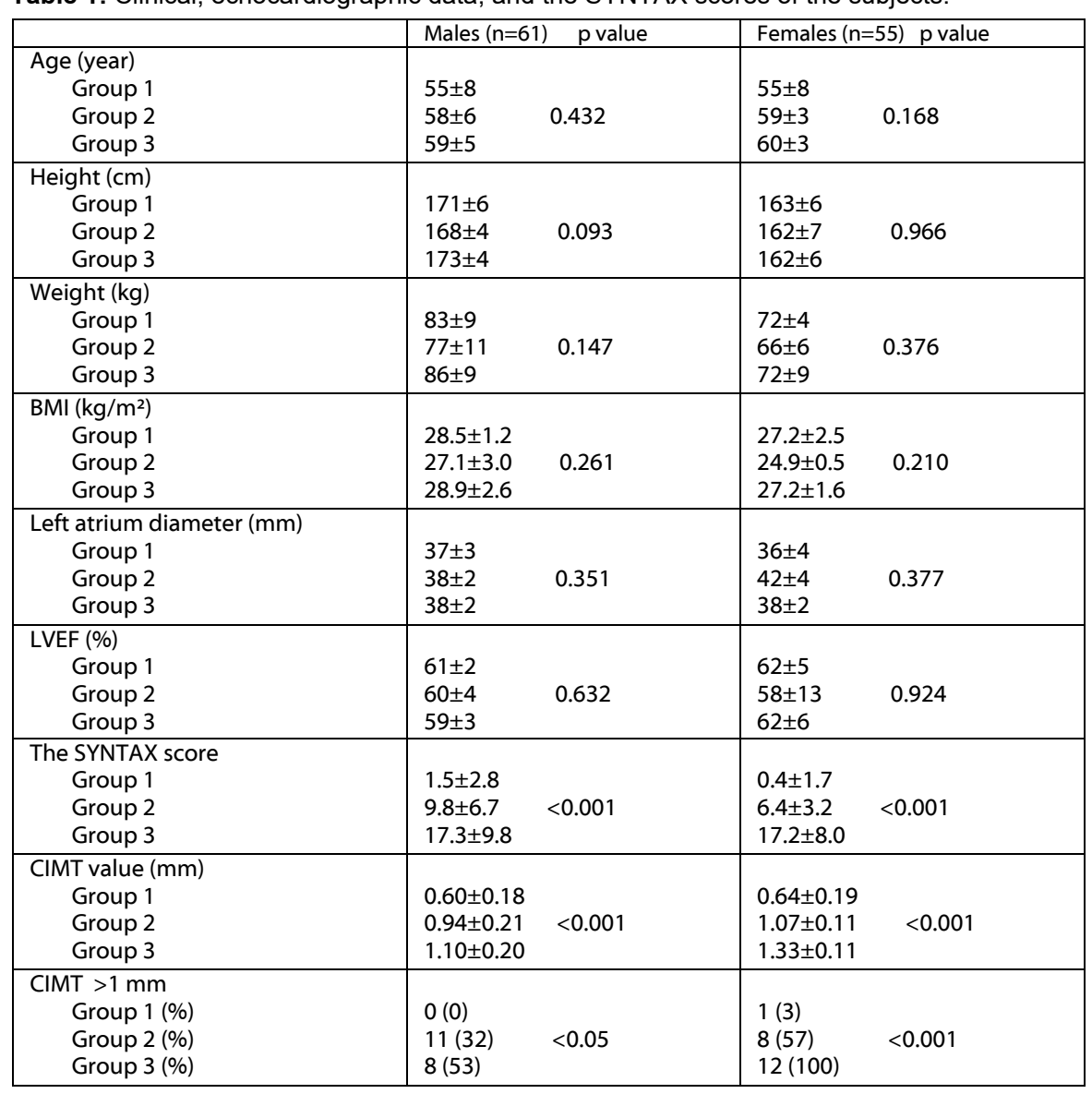

BMI: Body mass index; LVEF: Left ventricular ejection fraction;CIMT: Carotid intima media thickness

Table 2: The SYNTAX score categories of the subjects

\begin{tabular}{|c|c|c|c|c|c|c|}
\hline & \multicolumn{3}{|c|}{$\begin{array}{c}\text { Male } \\
\text { subjects }\end{array}$} & \multicolumn{3}{c|}{$\begin{array}{c}\text { Female } \\
\text { subjects }\end{array}$} \\
\hline $\begin{array}{l}\text { The SYNTAX } \\
\text { score }\end{array}$ & $\begin{array}{c}\text { Group 1 } \\
(\mathbf{n = 1 2 )}\end{array}$ & $\begin{array}{c}\text { Group 2 } \\
(\mathbf{n = 3 4 )}\end{array}$ & $\begin{array}{c}\text { Group 3 } \\
(\mathbf{n = 1 5})\end{array}$ & $\begin{array}{c}\text { Group 1 } \\
(\mathbf{n = 2 9 )}\end{array}$ & $\begin{array}{c}\text { Group 2 } \\
(\mathbf{n = 1 4 )}\end{array}$ & $\begin{array}{c}\text { Group 3 } \\
(\mathbf{n}=\mathbf{1 2})\end{array}$ \\
\hline Zero & 8 & 2 & 0 & 27 & 1 & 0 \\
\hline $1-22$ & 4 & 30 & 12 & 2 & 13 & 8 \\
\hline $23-32$ & 0 & 1 & 2 & 0 & 0 & 4 \\
\hline$\geq 33$ & 0 & 1 & 1 & 0 & 0 & 0 \\
\hline
\end{tabular}


Frequency of major cardiovascular risk factors and laboratory findings of the subjects were expressed in Table 3 and 4 accordingly.

The SYNTAX score was significantly correlated with CIMT value both in male $(\mathrm{r}=0.894 \mathrm{p}<0.001)$ and female subjects $(\mathrm{r}=0.840 \mathrm{p}<0.001)$. Average CIMT value of zero-score male patients $(n=10)$ had significantly lower value than that of low-risk SYNTAX score $\quad(\mathrm{n}=46) \quad(0.51 \pm 0.09 \quad$ vs. $0.96 \pm 0.20 ; \mathrm{p}<0.001, \mathrm{z}$ score -4.968$)$. Similarly, Average CIMT value of zero-score female patients $(n=28)$ had significantly lower value than that of low-risk SYNTAX score $(\mathrm{n}=23)$ $(0.64 \pm 0.20$ vs. $1.14 \pm 0.18 ; \mathrm{p}<0.001, \mathrm{z}$ score -5.648).

In logistic regression analysis, only presence of AGA was shown to be indicator of SYNTAX $>22$ in the model including cardiovascular risk factors and presence of AGA for both males and females $\left(\beta=1.629, \mathrm{r}^{2}=0.521\right.$, $\mathrm{p}<0.001$ and $\beta=5.822 \quad \mathrm{r}^{2}=0.827$, $\mathrm{p}<0.001$ respectively).

\section{Discussion}

AGA is hereditary hair loss induced by the effect of androgenic hormones in individual with genetic tendency (1). This develops from third decade onwards in males. DHT plays pivotal role in development of male pattern baldness. Female AGA is generally not related with elevated androgens as male AGA. Rather, women with female AGA may have other dermatological or general findings of hyperandrogenism. Still there are some controversial results about relation between AGA and presence of CAD. Here, we searched the relation between AGA and CAD by the help of the SYNTAX score which is direct, objective and quantitative tool to measure extent and severity of coronary atherosclerosis and CIMT which is noninvasive tool reflecting peripheral vascular atherosclerosis.

There have been studies indicating relation of AGA with cardiovascular risk factors $(15,16)$. But some of them reported relation with only hyperten- sion rather than diabetes and hyperlipidemia (17). These conflicting results may be due to heterogenity of the population in concern, duration and onset of AGA, multifactorial character of underlying AGA mechanism. In our study, the frequency of cardiovascular risk factors were similar between the groups and also we didn't have a control group to evaluate between the patients with AGA and a control group in respect to frequency of cardiovascular risk factors. One of the reason for this result can be due to different exposure time of the subjects to underlying AGA mechanisms both in our study and previous studies. Otherwise, it was known that early-onset AGA was related to premature CAD and cardiovascular risk factors (4).

The SYNTAX (Synergy Between PCI With Taxus and Cardiac Surgery) score was produced as part of the SYNTAX trial aiming at characterizing and objectively quantifying the severity and extent of CAD (18). Application of the SYNTAX score was tested in several studies and found to be beneficial to predict adverse events in patients undergoing coronary intervention (19). Thus it reflects actual and objective state of the coronary artery involvement. Several studies have been carried out regarding relation between AGA and CAD, but our study was unique since we used the SYNTAX score to define severity of CAD together with CIMT, a noninvasive indicator of peripheral atherosclerosis instead of hypothetical classification of presence of CAD as done before. Also we included female AGA in our study in similar fashion.

Atherosclerosis is directly related to presence of cardiovascular risk factors as known. In our study, the number of risk factors was similar across the groups. However, atherosclerotic burden was increased in parallel with AGA severity. It indicated that atherosclerotic burden was mainly related to AGA severity rather than direct effect of cardiovascular risk factors in the study population. In the logistic regression analysis, we showed that the presence of AGA was the only indicator of SYNTAX $>22$ among cardiovascular risk factors and AGA severity both for males and females. High number of cardiovascular risk factors can be expected for patients with higher SYNTAX score in the general population, however this is a cross sectional study performed among patients with AGA similar to the study by Vayá et al. (20).

AGA inherited with a complex polygenic pattern as cardiovascular disease (3).

Tablo 3: The frequency of cardiovascular risk factors among the groups

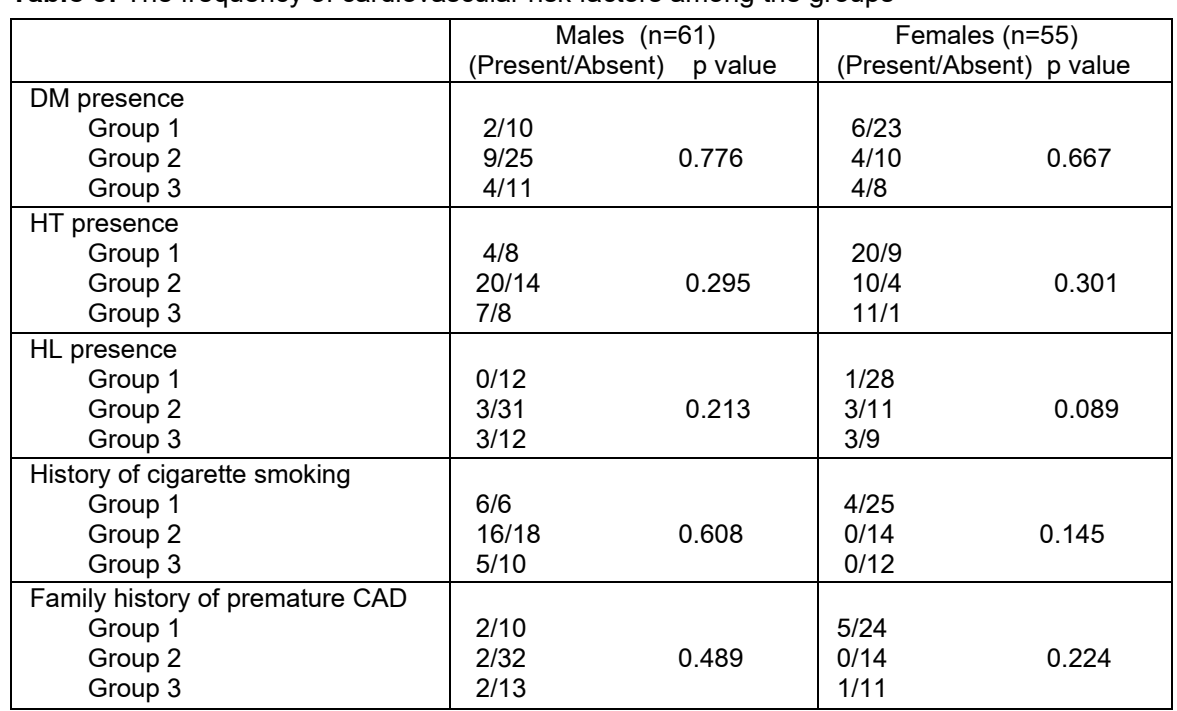

DM: Diabetes mellitus; HT: Hypertension; HL: Hyperlidemia; CAD: Coronary artery disease 
Increased serum DHT/testosterone ratio rather than elevated serum testosterone level is important in the pathophysiology (5-7). In the study by Rebora et al., patients with early-onset AGA before 40 years old had higher cardiovascular burden and higher DHT/Testosterone ratio than the others (21). Also it is known that there is a link between AGA and insulin resistance (22). However, it may need longer duration to get in effect. Age also has an effect on hair loss especially after 50 years old (23). Our study population was relatively young with average age of $57 \pm 6$ years for both males and females. Also age was controlled for all groups in males and females respectively $(p=0.432$ and 0.168 respectively). Thus, frequency of diabetes mellitus did not differ statistically among groups for both genders.

Patients with SYNTAX score of $\geq 33$ was defined as high risk and benefited from coronary by-pass surgery

\section{REFERENCES}

1. Stough D, Stenn K, Haber R, et al. Psychological effect, pathophysiology, and management of androgenetic alopecia in men.Mayo Clin Proc. 2005;80:1316-1322.

2. Piraccini BM, Alessandrini A. Androgenetic alopecia.G Ital Dermatol Venereol. 2014;149:15-24.

3. Hogan DJ, Chamberlain M. Male pattern baldness.South Med J. 2000;93:657-662.

4. Sharma KH, Jindal A. Association between androgenetic alopecia and coronary artery disease in young male patients. Int J Trichology. 2014;6:5-7.

5. Traish AM. Adverse health effects of testosterone deficiency (TD) in men. Steroids. 2014;88:106-16.

6. Agac MT, Bektas H, Korkmaz L, et al. Androgenetic alopecia is associated with increased arterial stiffness in asymptomatic young adults. J Eur Acad Dermatol Venereol. 2014 Mar 14. doi: 10.1111/jdv.12424. [Epub ahead of print].

7. Vigen R, O’Donnell CI, Barón AE, et al. Association of testosterone therapy with mortality, myocardial infarction, and stroke in men with low testosterone levels. JAMA. 2013;310:1829-1836 while patients with score of $\leq 22$ was classified as lor risk and offered to perform percutaneous coronary intervention for the treatment of obstructive CAD. According to the SYNTAX scoring, zero score indicates either normal coronary arteries or CAD without clinical importance but necessitating medical therapy. In our study, all the patients with zero SYNTAX score had normal coronary artery anatomy in coronary angiography. To confirm these results, we performed CIMT measurement. Average CIMT value of zero-score male patients had significantly lower value than that of low-risk SYNTAX score. Similarly, Average CIMT value of zero-score female patients had significantly lower value than that of lowrisk SYNTAX score. In the study by Korkmaz et al., CIMT was found to be associated independently with the SYNTAX score (24). We found that patients with higher AGA stages had higher SYNTAX score and advanced stage of SYNTAX category both in males and females. With these results we proved directly relation between AGA and CAD.

As a secondary outcome of the study, we found that patients with higher AGA stages had significantly higher CIMT values without gender preference indicating presence of vascular atherosclerosis in relevant subjects. Thus, it may be suggested that phenotypical appearance of the patients can give direct clue for possible presence of cardiovascular atherosclerosis.

In conclusion, AGA is common cosmetically disturbing health problem for both gender, but beyond that, it may be a simple phenotypical indicator for cardiovascular atherosclerosis. We found that patients with higher stage of AGA had significantly higher the SYNTAX score and CIMT value among both gender.

Üniversitesi Tip Fakültesi Mecmuası. 2015;68:9-14.

14. Ludwig E. Classification of the types of androgenetic alopecia (common baldness) occurring in the female sex. Br J Dermatol. 1977;97:247-254.

15. Trieu N, Eslick GD. Alopecia and its association with coronary heart disease and cardiovascular risk factors: a metaanalysis. Int J Cardiol. 2014;176:687-695.

16. Arias-Santiago S, Gutiérrez-Salmerón MT, Castellote-Caballero L, et al. Androgenetic alopecia and cardiovascular risk factors in men and women: a comparative study. J Am Acad Dermatol. 2010;63:420-429.,

17. Ahouansou S, Le Toumelin P, Crickx B, et al. Association of androgenetic alopecia and hypertension. Eur J Dermatol. 2007;17:220-222.

18. Sianos G, Morel MA, Kappetein AP, et al. The SYNTAX score: an angiographic tool grading the complexity of coronary artery disease. EuroIntervention 2005;1:219-27.

19. Yadav M, Palmerini T, Caixeta A, et al. Prediction of coronaryrisk by SYNTAX and derivedscores: synergy between per- 
cutaneous coronary intervention with taxus and cardiac surgery. J Am Coll Cardiol. 2013;62:1219-1230.

20. Vayá A, Sarnago A, Ricart JM, et al. Inflammatory markers and Lp(a) levels as cardiovascular risk factors in androgenetic alopecia. Clin Hemorheol Microcirc. 2016;61:471-477.
21. Rebora A. Baldness and coronary artery disease: the dermatologic point of view of a controversial issue. Arch Dermatol. 2001;137:943-947.

22. Bakry OA, Shoeib MA, El Shafiee MK, et al. Androgenetic alopecia, metabolic syndrome, and insulin resistance: Is there any association? A case-control study. Indian Dermatol Online J. 2014; 5:276-281.
23. Mirmirani P. Age-related hair changes in men: Mechanisms and management of alopecia and graying. Maturitas. 2014 Oct 23. doi: 10.1016/j.maturitas.2014.10.008. [Epub ahead of print].

24. Korkmaz L, Bektas H, Korkmaz AA, et al. Increased carotid intima-media thickness is associated with higher SYNTAX score. Angiology. 2012;63:386-389. 